service, how appropriate were the actions deputies took as a result of the consultations? Questions like these in relation to deputizing services are as timely as they are overdue for answering in relation to general practice as a whole.

Some ideas about how deputizing services are being staffed were not borne out in relation to the B.M.A. Deputizing Service in Sheffield. The deputies were not recently qualified doctors, nor were they doctors from overseas temporizing till they could settle in regular medical employment. ${ }^{2}$ Most of the work was undertaken by junior hospital doctors, however. They had been qualified on average for six years and were, in the main, registrars or senior registrars established on training ladders. It is likely, therefore, that they were motivated to work for a deputizing service by financial reasons rather than a desire to acquaint themselves with one aspect of general practice. Although the hospital doctors dealt with nearly a half of the calls attended to after midnight, in the absence of information about the off-duty time available to them in their hospital posts no comment can be offered about the possibility of conflict between their work for the deputizing service and their hospital responsibilities.

The deputizing undertaken by the general-practitioner deputies, however, clearly made few inroads into their off-duty time and was unlikely to have affected their availability to their own patients. Very little is known about how primary medical care is being delivered "out of hours." There is no information at present about the proportion of "out-of-hours" calls being handled by patients' own general practitioners, by their doctors' partners, by doctors in an off-duty rota, or by deputizing service doctors. Until we have this information we are in no position to measure the real impact deputizing services are making.

We are grateful to the Central Advisory Committee, B.M.A. Deputizing Services, and to Air-Call Ltd. for enabling us to undertake this study; to the Clerk of the Sheffield Executive Council for information; to Mrs. J. Lay, of the Science Research Council Atlas Computer Laboratory, for computing help; and to Mrs. M. Dick, Mrs. C. Sammans, Miss M. Beddard, Miss J. Rhodes, and Miss S. Boot for technical and clerical help.
APPENDIX-Large Towns with Deputizing Services

\begin{tabular}{|c|c|c|c|}
\hline $\begin{array}{l}\text { Accrington } \\
\text { Belfast } \\
\text { Birkenhead } \\
\text { Birmingham } \\
\text { Blackburn } \\
\text { Bolton } \\
\text { Bootle } \\
\text { Bradford } \\
\text { Bristol } \\
\text { Bury } \\
\text { Burnley } \\
\text { Cardiff } \\
\text { Coventry }\end{array}$ & $\begin{array}{l}\text { Dewsbury } \\
\text { Dudley } \\
\text { Edinburgh } \\
\text { Gateshead } \\
\text { Glasgow } \\
\text { Huddersfield } \\
\text { Kingston-upon- } \\
\text { Hull } \\
\text { Leeds } \\
\text { Leicester } \\
\text { Liverpool } \\
\text { London } \\
\text { Manchester }\end{array}$ & $\begin{array}{l}\text { Newcastle } \\
\text { Nottingham } \\
\text { Oldham } \\
\text { Paisley } \\
\text { Preston } \\
\text { Rochdale } \\
\text { Rotherham } \\
\text { St. Helens } \\
\text { Salford } \\
\text { Sheffield } \\
\text { Solihull } \\
\text { Southend } \\
\text { Southampton }\end{array}$ & $\begin{array}{l}\text { South Shields } \\
\text { Stockport } \\
\text { Stoke-on-Trent } \\
\text { Sunderland } \\
\text { Teesside } \\
\text { Tynemouth } \\
\text { Wallasey } \\
\text { Walsall } \\
\text { Warley } \\
\text { Warrington } \\
\text { West Bromwich } \\
\text { Wigan } \\
\text { Wolverhampton }\end{array}$ \\
\hline
\end{tabular}

\section{References}

1 Department of Health and Social Security, Organization of Group Practice. Report of Sub-Committee of Standing Medical Advisory Committee. London, H.M.S.O., 1971.

2 Hansard, Parliamentary Debates, House of Lords, 25 Feb. 1969, vol. 299. General Register Office, Sample Census 1966. England and Wales. County Report. Yorkshire, West Riding. London, H.M.S.O., 1967.

- General Register Office, Studies on Medical and Population Subjects, No. 9. London, H.M.S.O., 1955.

6 Williams, W. O., Royal College of General Practitioners, Reports from General Practice, No. 12. London, R.C.G.P., 1970.

- Ministry of Health, Fieldwork of the Family Doctor (Gillie Report). London, H.M.S.O., 1963.

' Royal Commission on Medical Education, 1965-8, Report, Cmnd. 3569. London, H.M.S.O., 1968.

8 Workinz Party of the British Medical Association's Planning Unit, Primary Medical Care (Report No. 4). London, British Medical Association, 1970.

- Scottish Home and Health Department, Doctors in an Integrated Health Service. Edinburgh, H.M.S.O., 1971 .

10 Royal College of General Practitioners, Reports from General Practice, No. 13. London, R.C.G.P., 1970.

11 Wright, H. J., Royal College of General Practitioners, Reports from General Practice, No. 8. London, R.C.G.P., 1968.

12 Fry, J., British Medical fournal, 1952, 2, 249.

13 Brotherston, J. H. F., and Cartwright, A., British Medical fournal, 1959, 2, 1169.

14 Stevenson, J. S. K., British Medical fournal, 1964, 1, 1370.

15 Webster, G. L., Ritchie, A. F., Morrell, J. A. L., and Scaife, B., British Medical fournal, 1965, 1, 1269.

16 Cartwright, A., Patients and their Doctors. London, Routledge and Kegan Paul, 1967.

17 Department of Health and Social Security, Annual Report, Cmnd. 4741 London, H.M.S.O., 1970.

18 Royal College of General Practitioners and Office of Population Censuses and Surveys, Classification of Morbidity for the National Morbidity Survey 1970-71. London, H.M.S.O., 1972.

\title{
Hospital Topics
}

\section{Fallopian Tube Surgery for Reversal of Sterilization}

\author{
GEOFFREY F. J. WILLIAMS
}

British Medical fournal, 1973, 1, 599-601

\section{Summary}

Of 16 consecutive cases of previous sterilization treated by tubal surgery fifteen women tested had patent Fallopian tubes. Over 18 months since operation there were four full-term pregnancies and two abortions among 11 patients. At interview with the patient it is important to emphasize that reconstruction of the tubes is a major

Bronglais General Hospital, Aberystwyth, Cardiganshire GEOFFREY F. J. WILLIAMS, M.B., F.R.C.o.G., Consultant Obstetrician and Gynaecologist operation and carries an increased subsequent hazard of ectopic pregnancy.

\section{Introduction}

The number of sterilizations performed on women has been steadily increasing over the years and has been boosted by the number done as an adjunct to abortion. The Registrar General's figures for 1968 showed 23,641 legal abortions, 5,128 of which were accompanied by sterilization, whereas in 1970 the figures had risen to 86,565 abortions, 13,946 accompanied by sterilization. ${ }^{1}$ Follow-up reviews of patients sterilized have varied in their findings but all have agreed that most are pleased to have had the operation. 
To a tiny minority, however, the operation has posed a difficulty. Thinking their family complete, they have agreed to the operation and then either because of death of the children or divorce or the death of the husband and subsequent remarriage, they have wanted another child. The popular type of sterilization such as the Pomeroy or its many modifications has left them with a fair amount of tube including the important fimbriated end. The remaining tube is healthy, the patient is known to be fertile, and apart from the blockage and by now being in an older age group, has everything in her favourthough some doubt has been expressed whether in future this will remain true after laparoscopic diathermy sterilization. ${ }^{2}$

A questionnaire ${ }^{3}$ to which 350 consultant gynaecologists in Great Britain replied revealed only 42 cases where re-establishment of patency after sterilization had been attempted, and the largest series was four. The number of such cases, though they will increase as sterilization becomes even more popular, will still be very small for any individual gynaecologist. The present series of 16 (see table) consisted of only five cases from my own area in 18 years. The other 11 were referred by gynaecologists from other areas.

\section{Results}

The types of operation and the outcome were as shown in the table.

Type of Operation and Outcome in 16 Cases Under Review

\begin{tabular}{|c|c|c|c|c|}
\hline $\begin{array}{l}\text { Case } \\
\text { No. }\end{array}$ & $\begin{array}{l}\text { Age at Time } \\
\text { of Operation } \\
\text { and Date }\end{array}$ & Type of Operation & $\begin{array}{l}\text { Subsequent } \\
\text { Patency and } \\
\text { Date }\end{array}$ & $\begin{array}{l}\text { Pregnancy } \\
\text { and Date }\end{array}$ \\
\hline 1 & $3511 / 57$ & $\begin{array}{l}\text { Bilateral tubo-uterine } \\
\text { implant }\end{array}$ & See pregnancy & L.S.C.S. $12 / 60$ \\
\hline $\begin{array}{l}2 \\
3 \\
4\end{array}$ & $\begin{array}{l}351 / 63 \\
358 / 63 \\
246 / 66\end{array}$ & $\begin{array}{ll}\text { Impiant } & \text { " } \\
\text { " } & \text { " }\end{array}$ & 4"68. Both & $\begin{array}{l}\text { L.S.C.S. 12/63 } \\
\text { L.S.C.S. } 9 / 64\end{array}$ \\
\hline 5 & $362 / 69$ & $\begin{array}{l}\text { Bilateral end to end } \\
\text { anastomosis }\end{array}$ & $\begin{array}{l}\text { 5/69. Both } \\
\text { patent }\end{array}$ & \\
\hline 6 & $2410 / 69$ & " & $\begin{array}{l}\text { 7/70. Both } \\
\text { patent }\end{array}$ & \\
\hline 7 & $2810 / 69$ & $\begin{array}{l}\text { Bilateral tubo-uterine } \\
\text { implant }\end{array}$ & $\begin{array}{l}\text { 7/70. Both } \\
\text { patent }\end{array}$ & Abortion 4/71 \\
\hline 8 & $343 / 70$ & $\begin{array}{l}\text { R. tubo-uterine implant } \\
\text { (L. previously removed) }\end{array}$ & See pregnancy & L.S.C.S. 8/72 \\
\hline 9 & $3011 / 70$ & $\begin{array}{l}\text { R. tubo-uterine implant. } \\
\text { No tube on } \mathrm{L} \text {. }\end{array}$ & $\begin{array}{l}\text { 12/71. R. } \\
\text { patent }\end{array}$ & Abortion 3/71 \\
\hline 10 & $242 / 71$ & Bilateral salpingostomy & $\begin{array}{l}\text { 4/711. Both } \\
\text { patent }\end{array}$ & \\
\hline 11 & $432 / 71$ & $\begin{array}{l}\text { R. tubo-uterine implant. } \\
\text { L. end to end. }\end{array}$ & $\begin{array}{l}\text { 4/71. Both } \\
\text { patent }\end{array}$ & \\
\hline 12 & $347 / 72$ & $\begin{array}{l}\text { Bilateral tubo-uterine } \\
\text { implant }\end{array}$ & $\begin{array}{l}\text { 9/711. Both } \\
\text { patent }\end{array}$ & \\
\hline 13 & $317 / 72$ & Bilateral end to end & $\begin{array}{l}\text { 9/71. Patent } \\
\text { on L. }\end{array}$ & \\
\hline 14 & $329 / 72$ & $" \quad \quad "$ & $\begin{array}{l}\text { Both patent } \\
10 / 72\end{array}$ & \\
\hline 15 & $349 / 72$ & $\begin{array}{l}\text { R. tubo-uterine implant. } \\
\text { L. tube and ovary } \\
\text { previously removed }\end{array}$ & 10/72. Patent & \\
\hline 16 & $4310 / 72$ & $\begin{array}{l}\text { L. end to end anasto- } \\
\text { mosis. R. tube } \\
\text { previously almost } \\
\text { completely removed }\end{array}$ & Not yet tested & \\
\hline
\end{tabular}

Over 18 months had elapsed since operation in 11 of the 16 cases. There were four full-term pregnancies and two abortions, a $55 \%$ conception rate. All of the 15 patients tested were patent. Kymography, screening, and hysterosalpinograpy were performed under anaesthesia as day cases. It should be noted that in one case in which sterilization was by fimbriectomy the patient was treated by salpingostomy, the results of which are likely to be very much poorer than either tubo-uterine implant or end to end anastomosis.

\section{Discussion}

\section{INTERVIEW WITH PATIENT AND HUSBAND}

It is usually possible to obtain operation notes of the type of sterilization performed before seeing the patient, and a full seminal examination of the husband should also be available.
It is important to impress on the couple that this is a major operation though the morbidity and mortality are very low. ${ }^{3}$

The important questions to the patient are the percentage chances of patency of the tubes and of pregnancy; to some of these women patency is as important as pregnancy. In a second marriage she is sometimes more interested in giving her husband the chance of a child, and after the operation he can never say he did not have this chance even if they do not succeed in conceiving. There is no authority to quote in answer to these questions. Palmer ${ }^{5}$ gave a $75 \%$ patency rate for tubo-uterine implantation in a series of patients, many of whom did not have such normal tubes as poststerilization cases. On similar patients Peel $^{6}$ found a $55 \%$ patency rate. Green-Armytage ${ }^{7}$ reported a series of 50 cases of tubo-uterine implantation for cornual blockage not after sterilization with a pregnancy rate of $40 \%$, Shirodkar ${ }^{8}$ reported a pregnancy rate of $35-40 \%$ in cases which might be comparable to poststerilization cases, and Seigler ${ }^{\circ}$ reported 12 cases of previously sterilized patients with a pregnancy rate of $42 \%$. My own series suggests an $80-100 \%$ patency rate and a $40-50 \%$ pregnancy rate.

It is imperative to stress the danger of ectopic pregnancy, the incidence of which in those patients who subsequently become pregnant is $15-20 \%$. The patient must have this explained to her in detail together with the warning that lower abdominal pain or a missed period should make her seek expert advice. The ratio of the outcome of conceptions is probably $15-20 \%$ ectopics, $65-70 \%$ full-term pregnancies, and $15 \%$ abortions-the latter figure being the same as in normal pregnancies. $^{3}$

The stay in hospital is normally 12-14 days. Intercourse should be avoided till after the first period and contraception should be practised for three months postoperatively. If the contraceptive pill is used, this means starting it before the operation, which is performed early in the menstrual cycle.

\section{FINDINGS AT LAPAROTOMY}

The object of the operation is to leave the fimbriated or salpingostomy end near the ovary and to have as long a length of tube as possible from there to the uterine cavity. Four types of findings or combinations of findings are present (see fig.).

Type 1 gives the possibility of initial end to end anastomosis, and if it fails subsequent tubo-uterine implantation. In any type of reconstruction it is advisable always to attempt both sides if this is possible.

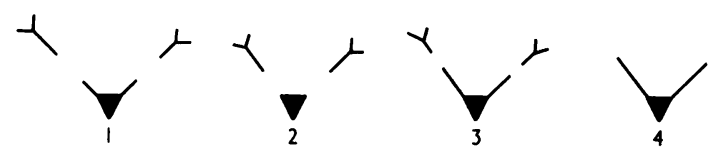
Four types of findings or combinations of findings at laparotomy. 1, Suitable tor tubo-uterine implantation or end to end anastomosis. 2, Suitable for suitable for salpingostomy.

\section{POINTS REGARDING OPERATION}

Tubo-uterine implantation, which is used in type 1 and type 2 findings, was first performed in 1896, and may be performed by the open fundal transverse incision described by Stallworthy ${ }^{10}$ or by reaming a tunnel as described by Holden and Sovak ${ }^{11}$ and perfected by Johnstone, ${ }^{12}$ Green-Armytage, ${ }^{13}$ and Shirodkar. ${ }^{8}$ It may be performed either with or without solid polyethylene tubing as a splint. In the present series all cases were performed with a $9-\mathrm{mm}$ reamer and solid polyethylene tubing $(1.2 \mathrm{~mm})$ brought down through the cervix and vagina. Oxytocin injection (Pitocin) $2 \frac{1}{2}$ units in $5 \mathrm{ml} \mathrm{N}$ saline was injected down each track before reaming to cut down haemorrhage, and the needles were left in as a guide for the reamer. Antibiotics were used for five days postoperatively and the polyethylene tubes 
removed on the 12 th day. No attempt was made to use chymotrypsin, cortisone generally or by hydrotubation, or to produce a three-month amenorrhoea postoperatively with steroids.

The technique of end to end anastomosis, which may be used in type 1 and type 3 findings, has been described by Seigler ${ }^{\circ}$ who quoted seven cases. Three of these subsequently delivered at term and one had a tubal pregnancy. The uterine end of the tube is tested for patency with methylene blue after cutting the sealed end, and the fimbriated end tested with a probe. A very fine tube may be induced to pass the intramural part of the tube and is anchored to the infundibulopelvic ligament above and the cervix and vagina below. This acts as a splint for the anastomosis and is removed on the 12th day, though the uterus and tube have a tendency to reject it vaginally earlier than this. If end to end anastomosis is to be done on one side and tubo-uterine implant on the other it is better to do the latter side first.

Salpingostomy was performed by using Bonney's cuff technique. A splint of fine polyethylene, nylon thread, or silkworm gut, if this can be threaded down the intramural part of the tube, helps to keep the ostium open till healing occurs. The use of polyethylene tubing or spiral Teflon stents brought through the abdominal wall, anchored subcutaneously, and removed at eight weeks as an office procedure, has given a patency rate of $86 \%{ }^{14}$

\section{FOLLOW-UP}

These patients are known to be fertile but nevertheless should be investigated for anovulatory cycles postoperatively. The results of tubal operations in Britain can be ascertained by the computerization of operations records; but it is important for an honest prognosis that the follow-up of tubal surgery should be correlated as advocated by Williams in Britain, and Seigler" and Roland and Leisten ${ }^{14}$ in America.

I am grateful to all my gynaecological colleagues who, by referring cases, have made this paper possible, and to Professor A. C. Turnbull, University Hospital, Cardiff, for his encouragement and constructive criticism.

\section{References}

1 Registrar General. Statistical Review of England and Wales for the Year 1970. Supplement on Abortion. London, H.M.S.O., 1971.

Williams, E. A., British Medical fournal, 1971, 4, 297.

Williams, G. F. J., Lancet, 1969, 1, 825.

Williams, G. F. J., Lancet, 1968, 1, 1426.

5 Palmer, R., Proceedings of the Royal Society of Medicine, 1960, 53, 357.

- Peel, J. K., Proceedings of the Royal Society of Medicine, 1964, 57, 710 .

7 Green-Armytage, V. B., Fournal of Obstetrics and Gynaecology of the British Empire, 1959, 66, 32.

Shirodkar, V. N., Contributions to Obstetrics and Gynaecology, Edinburgh, 1960.

Seigler, A. M., Obstetrics and Gynecology, 1969, 34, 339.

Stallworthy, J. A., in British Obstetric and Gynaecological Practice, ed. A. Claye and A. Bourne, p. 756. London, Heinemann, 1963.

Holden, F. C., and Sovak, F. W., American fournal of Obstetrics and Gynecology, 1932, 24, 684. $12 \mathrm{Johnstone,} \mathrm{J.} \mathrm{W.,} \mathrm{Fournal} \mathrm{of} \mathrm{Obstetrics} \mathrm{and} \mathrm{Gynaecology} \mathrm{of} \mathrm{the} \mathrm{British} \mathrm{Empire,}$
$1959,62,410$.

13 Green-Armytage, V. B., fournal of Obstetrics and Gynaecology of the British Empire, 1957, 64, 47.

14 Roland, M., and Leisten, D., Obstetrics and Gynecology, 1972, 39, 57.

\title{
Inside Europe
}

\section{Clinical Medicine and Research in France}

\author{
C. T. DOLLERY, J. I. BURN
}

British Medical fournal, 1973, 2, 601-604

Britain and France are close together geographically and both have highly developed systems of medical care and invest substantial sums in medical research. Despite this the contacts between the two countries in medicine and medical research are not strong. A British clinician or medical scientist is more likely to know his counterpart in New York or San Francisco than in Paris or Marseille, and the same is true in France.

In January 1973 we undertook a two-week visit to Paris, Lyon, and Marseille on behalf of the British Council to discuss with French colleagues how Anglo-French co-operation might be improved. The itinerary of our visit was arranged in France by the Ministry of Public Health in

Royal Postgraduate Medical School, London W12 OHS

C. T. DOLLERY, M.B., F.R.C.P., Professor of Pharmacology

J. IAN BURN, F.R.C.S., Senior Lecturer and Consultant Surgeon

consultation with the Institut National de la Santé et de la Recherche Médicle, I.N.S.E.R.M.) and the Ministère des Affaires Etrangères. The centres we visited were selected by our French colleagues after preliminary discussions with due regard to our own particular individual interests in hypertension-nephrology and oncology.

\section{Language and Attitudes}

Neither of us is fluent in French although we both understand the spoken language reasonably well. Throughout our visit, therefore, we found that the most satisfactory arrangement was for our hosts to speak in French and for us to reply in English.

Most of the French physicians and scientists we met obviously understood English extremely well, it was clear that many of the younger doctors and research workers were fluent in the language. Most of the young research workers had spent one or two years in the U.S.A. and they now tend to write in English in international journals. 